\title{
The Method of Real Options to Encourage the R \& D Team
}

\author{
Junfeng Gao ${ }^{1}$, Lan Jiang ${ }^{2}$ \\ ${ }^{1}$ School of Management and Economics, University of Electronics Science and Technology of China, Chengdu, China; ${ }^{2}$ Tian Fu \\ College, Southwestern University of Finance and Economics, Chengdu, China. \\ Email: zhsing@163.com
}

Received February $21^{\text {st }}, 2010$; revised March $27^{\text {th }}, 2010$; accepted May $1^{\text {st }}, 2010$.

\begin{abstract}
In some projects, the $R \& D$ appears to be a failure, and according to traditional methods of encouragement motivation, it is hard to get any awards for the $R \& D$ team. But there is a valuable option implied in it. This article discusses the method of real options to encourage $R \& D$ team when the enterprises can not achieve the desired economic benefit in the case of high-risk project or the immature market. The process of method includes: Identify the real option type of high-risk projects, Design the incentive mechanism and Design specific exercise ways.
\end{abstract}

Keywords: The High-Risk $R \& D$ Project, Real Option Incentive, $R \& D$ Team

\section{Introduction}

The emphasis of the researchers in the enterprise is to explore or update new products or services, which requires high technology and strong innovation and needs inter-disciplinary team work and multi-professionals' participation. The collaboration of $\mathrm{R} \& \mathrm{D}$ project team requires companies to adopt collective rather than individual compensation system [1].

But team incentive is more complicated in actual work, especially in high risk R \& D project. When enterprises fail to achieve the desired economic benefit in the immature market, it is a big problem to motivate team effectively. It is unfair for the R \& D team if we deny its contribution, because the lessons at least can help us avoid similar risk, and the technology experience accumulated can establish good foundation for the latter project. If there is no reward, no one would do these high-risk projects or they maybe change job with these expensive experience. However, if the reward is paid, what is the criterion of incentive and how to evaluate contribution of the project should be considered. And this paper will introduce a new incentive method-real option incentive plan.

\section{A Brief Overview of Literature}

A team incentive system sends a message to employees that their team's output and performance is valued by the

The paper is supported by National Natural Science Foundation of China ( Project No. 70772069). organization [2]. If team performance is not rewarded, such performance is not likely to be optimal [3,4]. Existed literatures discuss many incentive ways to $\mathrm{R} \& \mathrm{D}$ from a management perspective, which are: 1) team gains sharing or profit-sharing, 2) team goal-based incentive systems. 3) team discretionary bonus systems, 4) team skill incentive systems, 5) team member skill incentive systems, 6) team member goal incentive systems, and 7) team member merit incentive systems [5]. The typical methods include spiritual incentives such as recognition, confer honor, promotion [6], and material incentives such as compensation incentive [7], stock incentive [8], stock option [9] and so on. However, because these incentives are based on different performance indicators, such as financial indicator, internal operating target and customer indicator [10], so can not solve the incentive problem of high-risk $\mathrm{R} \& \mathrm{D}$ project.

As an expansion of financial option theory in real (non-financial) assets option, real option change investors' view to risk and make them pay more attention to the value of opportunities [11]. In recent years, scholars have put forth real option incentive approaches for the executives [12] and R \& D personnel [13]. The former is to balance business investment and strategic investment, focus on guiding operators to develop the future strategic growth opportunities; the latter is based on the compounded options and relatively effective for the multistage technology projects or successful projects. But both do not come down to the incentive problems of high-risk $\mathrm{R} \& \mathrm{D}$ projects. There is little literature to discuss real 
option contained in high-risk projects which is more complecatied. For believing experiences in high-risk R \& $\mathrm{D}$ projects can create development opportunities for follow-up technology projects and help enterprises avoid risks, so we focus on how to identify such options created by these opportunities and to design effective incentive ways.

\section{The Comparison of Real Option and Other Incentive Ways}

There are many team incentive ways and compensation incentive is common. Compensation incentive is divided into two ways. One is fixed pay incentive based on projects' performance, such as improving all members' base pay or giving a raise, which has stronger short-term effect. When employees find there is a positive relationship between hard work and reward, the incentive effect is obvious; In addition, some key R \& D staff has generally higher level salary in the same industry after giving a raise several times and will not easily change jobs, which is favor of R \& D team's stability. However, this incentive is also controversial. One contention focuses on that reward is difficult to cut in the future and no flexibility, which often becomes a major cost burden. Another is it may let some people over-rely on historical performance in long-term and bring negative effect to follow-up research.

To avoid the shortcomings of the fixed salary many companies adopt another variable pay incentive, such as project incentive, profit-sharing plan, flexible salary system etc. The advantage of this incentive approach is that incentive compensation varies with the project performance, which is very flexible. But it belongs to short-term incentive and the effect does not last for a long time. In addition, the biggest drawback is it can not resolve the incentive problem of high-risk and store project. When a project can not obtain direct economic benefits or face failure, it is hard to find the incentive standard.

Team incentive also includes stock option and other forms, which are long-term incentives. The common practice is to give project team option that allows them to purchase a certain percentage of enterprise common stock according to pre-set price in a given period. When the price of stock increases, project team can share benefit from stock appreciation. But company's stock price may not related to a single project directly, and may be manipulated and fluctuate with the whole stock market. So this incentive effect is not direct. In addition, it also can not resolve the incentive standard problem of high-risk and store project.

To solve the above incentives' shortcoming, this paper design real option approach which can evaluate the highrisk R \& D project roundly, especially the value of potential risks, and establish a fair standard for incentive. The enterprises can adopt short-term or long-term incentive accordingly, such as exchanging the value of real option of the current project as bonus (short-term incentives), or allowing $\mathrm{R} \& \mathrm{D}$ team share the profit of latter project (long-term incentives). However this way needs many data and it is some difficult. The above methods of incentive are shown in Table $\mathbf{1 .}$

\section{The Design of Real Option Incentive}

In order to conduct real option incentive, we must identify the type of real option high-risk projects contained, and then design incentive scheme.

Table 1. The comparison of advantage and disadvantage of team incentive ways

\begin{tabular}{|c|c|c|}
\hline $\begin{array}{l}\text { Type of } \\
\text { incentives }\end{array}$ & Advantages & Disadvantages \\
\hline $\begin{array}{l}\text { fixed pay } \\
\text { incentives }\end{array}$ & $\begin{array}{l}\text { Stronger short-term incentive effect and in } \\
\text { favor of R \& D team's stability }\end{array}$ & $\begin{array}{l}\text { Lack of flexibility, often becomes a major cost burden. } \\
\text { Make some people over-rely on historical performance in long-term; bring } \\
\text { negative effect to follow-up research projects. }\end{array}$ \\
\hline $\begin{array}{l}\text { variable pay } \\
\text { incentives }\end{array}$ & $\begin{array}{l}\text { Incentive compensation varies with the } \\
\text { project performance, very flexible; } \\
\text { The effect does not last for a long time. }\end{array}$ & $\begin{array}{l}\text { Hard to find the incentive standard; } \\
\text { Can not resolve the incentive problem of high-risk and store project }\end{array}$ \\
\hline Stock option & $\begin{array}{l}\text { Income is comparative with performance } \\
\text { and risk, } \\
\text { Have a long-term incentive effect }\end{array}$ & $\begin{array}{l}\text { Company's stock price may not relate to a single project directly, and may be } \\
\text { manipulated and fluctuate with the whole stock market. } \\
\text { Cannot resolve the incentive standard problem of high-risk and store project }\end{array}$ \\
\hline Real option & $\begin{array}{l}\text { Can evaluate the project roundly, especially } \\
\text { the value of potential risks, and establish a } \\
\text { fair incentive standard; And enterprises can } \\
\text { adopt short-term or long-term incentive } \\
\text { accordingly }\end{array}$ & Needs many data and difficult \\
\hline
\end{tabular}




\subsection{Identify the Real Option Type of High-Risk Projects}

Although not to achieve good financial returns, high-risk $\mathrm{R} \& \mathrm{D}$ projects can bring enterprise a lot of intangible resources and capabilities, which includes the accumulation of knowledge, technical capabilities, project organizational skills in the field, etc.; even includes innovation network resources, some Know-How or technology patents. These intangible resources and capabilities at least can help enterprises avoid risks, reduce losses in followup projects, as well as provide more opportunities for enterprises' development. Enterprises can make full use of these opportunities in the future, and from which we can identify opportunities value of project in different situations and the corresponding type of real option, as shown in Table 2.

\subsection{Design the Incentive Mechanism}

In this incentive mechanism, the income of R \& D team is composed of salary and a part of the value of real option:

$$
I=A+\sum V_{i}
$$

In Equation (1):

" $I$ " means the income of $\mathrm{R} \& \mathrm{D}$ team.

" $A$ " means annual fixed salary.

" $V_{i}$ " is the bonus that $\mathrm{R} \& \mathrm{D}$ team shared with the value of real option in project No. $\mathrm{i}$.

$$
V_{i}=\left\{\begin{array}{lr}
\alpha_{i} C & N P V \leq 0 \\
\alpha_{i}(N P V+C) & N P V>0
\end{array}\right.
$$

In Equation (2), when Net Present Value (NPV) of project with traditional methods is negative or equal to zero, we should regard the value of real option $C$, not $N P V$ as the value of the project, because there is no significance for $N P V$ if the project is given up or switched. When $N P V$ is positive, we should regard total value, that is the sum of $N P V$ and real option value of $C$, as the value of the project, because which can reflect the current and future performance more comprehensively.
In Equation (2), $\alpha_{i}$ is the proportion of the value of project No. i. The value of $\alpha_{i}$ depends on R \& D team's contribution rate to total project. Calculation of contribution rate may refer to the method of calculating the distribution of technical factors (at this time revenue of the project should be regarded as the value of total project), which presented in some relevant literature [14,15]. When calculate total value of the project, we should consider it separately according to $N P V \leq 0$ or $N P V>0$. Generally speaking, when $N P V \leq 0$, the value of $\alpha_{i}$ should be larger. In practice, the value of $\alpha_{i}$ is also determined by three factors: firstly, by the specific business target and strategic objective; secondly, by the competition for talent within the industry; Thirdly, by the result of negotiation and game between firms and $\mathrm{R} \& \mathrm{D}$ team, which depends on both sides' dominant position and information symmetry, etc.

\subsection{Design Specific Exercise Ways}

There are many exercise ways of real option incentive. For example, if exchange option value to a certain percentage of bonus, it can be seen as a European-style two-value put option, and when the project achieved its purpose, the option seller would pay a pre-agreed reward. If total value of the current project (including $N P V$ and the value of real option) can be shared by the $R \& D$ team, actually it can be considered as call option, which allows team to share the profits of the follow-up project or sell a part of stock for arbitrage at higher price. In practice, call option includes American or European option, American option allows its holders to buy or sell the subject at any time of the validity, and European option allows only implementation at the due date. If it is American option, which means option holder will be allowed to share equity of the follow-up project at the agreed price (or dynamic price in accordance with one method) before the appointed time. In fact the two options can be used as incentive, and usually American option's operation is more complex than European option's.

Table 2. The type of real option contained in high-risk projects

\begin{tabular}{ll}
\hline \multicolumn{1}{c}{ The action of high-risk projects } & \multicolumn{1}{c}{$\begin{array}{l}\text { Corresponding type of real } \\
\text { option }\end{array}$} \\
$\begin{array}{l}\text { experience and lesson can help enterprises } \\
\text { avoid risks in follow-up projects }\end{array}$ & $\begin{array}{l}\text { Well identify risk and reduce loss by deferring investment, } \\
\text { contracting investment, giving up investment }\end{array}$ \\
$\begin{array}{l}\text { The option to defer } \\
\text { Thore opportunities for enterprises' develop- } \\
\text { ment }\end{array}$ & $\begin{array}{l}\text { Build foundation for similar technical upgrading. } \\
\text { Intangible assets accumulated facilitate to enterprises' ex- } \\
\text { panding in future. }\end{array}$ \\
\hline
\end{tabular}

Classification of real option comes from [11] 


\section{A Case of Real Option Incentive}

Take option to switch for an example, we collect the relevant data of a $\mathrm{R} \& \mathrm{D}$ project of a high-technical company to test it. Located in China, this company mainly engaged in developing $3 \mathrm{G}$ communication technology. In early 2007 the company conducted 3G-based mobile software, and its R \& D developed in three phases. Its original input cost is 60 million. Every year, each phase can be finished with generation I, II, III of product A. And the product can be replicated and sold. This project was influenced greatly by the State's policy on $3 \mathrm{G}$, and faces a high market risk. Based on past similar project data analysis, the market was forecasted to have a good probability of 40 percent, the probability of a bad market at $60 \%$. After the first year, if the market is good, we can get the profit of 60 million; if the market is not good the profit is 12 million. In the following two years, if the market is good the profit is high and cash flow will double on the basis of the former year, but in the poor market cash flow is only half of the former year. Let's select the company's comprehensive capital-cost as a risk discount rate $(20 \%)$, and calculate the net cash flow (NPV).

E.g., in the good market condition of the former two years, the expected value of cash flow in the second year:

$$
(240 \times 0.40+60 \times 0.60) \div(1+20 \%)=110
$$

Similarly, we can calculate other discounted value of net cash flow in every phase, result shown in Figure 1. The final $N P V$ expected value is 11.68 million:

$$
71.68-60=11.68
$$

So this project is worth to invest with $N P V$ method.

\subsection{Traditional Incentive Idea}

However, in fact after one year market has changed, and we found some competitors appeared, and the probability of good or poor market would become $20 \%$ and $80 \%$ in the next year, but the risk probability of market was unchanged in the following 2 years. At the same time the project get one patent that can be grounded for another product and some enterprises will bid 50 million for it. Obviously, when the first phase of R \& D was completed, the $N P V$ was negative:

$$
\begin{aligned}
N P V & =[(105.42+60) \times 0.2+(21.08+12) \times 0.8] \\
& \div(1+20 \%)-60=-10.38
\end{aligned}
$$

That means the project was failed, so R \& D team can not get any encouragement according to traditional compensation or stock option incentive way.

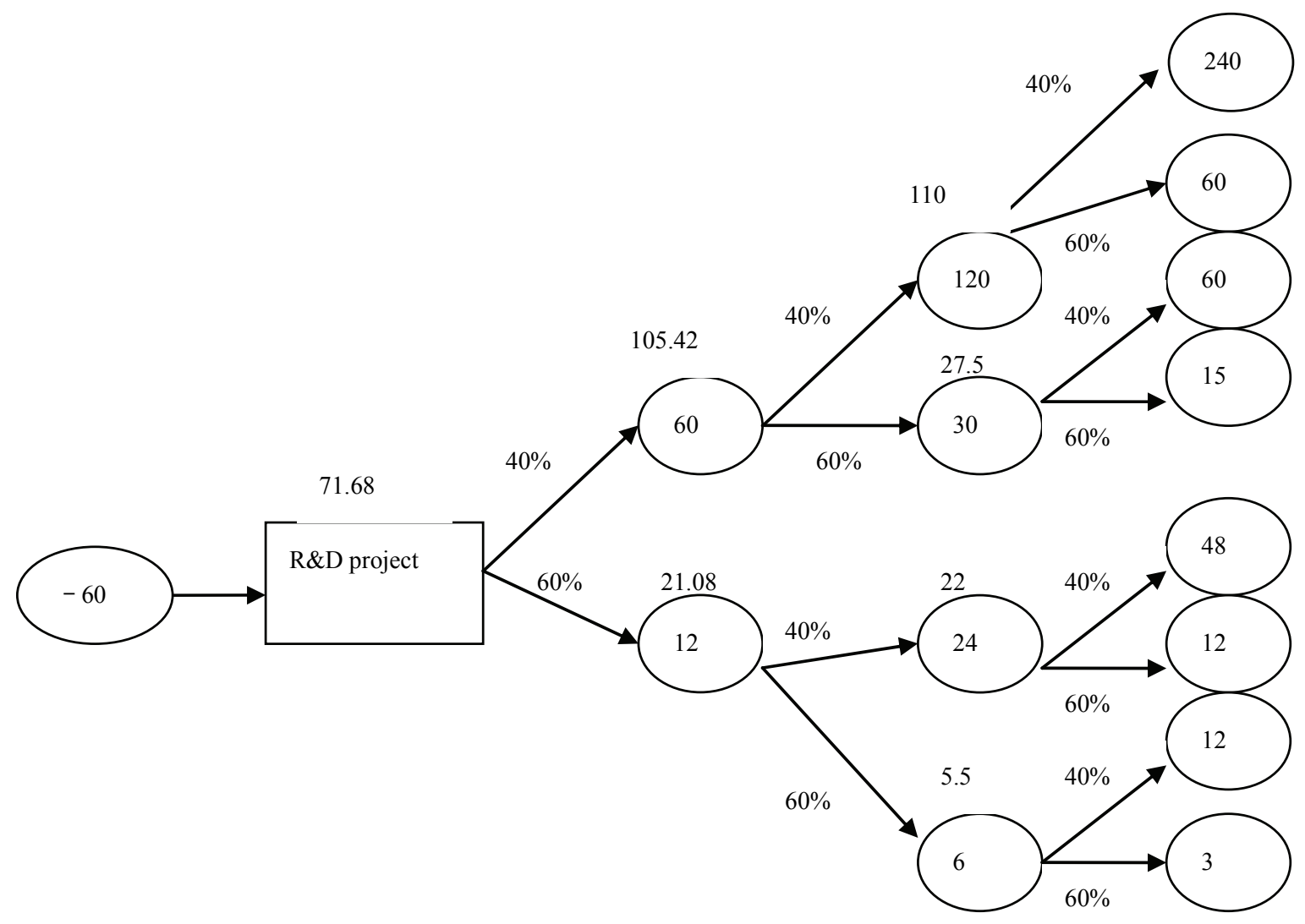

Figure 1. The cash flow of the project 


\subsection{Real Option Incentive Program}

Now if we consider real option, the evaluation to the project is entirely different. When R \& D in the first phase was completed, cash flow was only 33.08 million in the poor market (that is, cash flow expected value after one year in poor market: $21.08+12=33.08$ ), if we switched to another product at this time, the value of the previous R \& D was 50 million. Obviously, such a conversion opportunity is valuable. Actually it is option to switch: the agreed price is 50 million, maturity period is 1 year, the current price of the subject is 49.62 million (hat is, expected value of current cash flow, $[(105.42+60)$ $\times 0.2+(21.08+12) \times 0.8] \div(1+20 \%)=49.62)$, maybe rise to 165.42 million (that is, expected value of cash flow after one year in good market: $105.42+60=165.42$ ) or drop to 33.08 million due to date (that is, expected value of cash flow after one year in poor market: $21.08+12=33.08)$. We can use binomial tree model [16] and set up the probability of price raise is " $P$ ". With the hypothesis of symmetric information and risk-neutral, we can get the value of this real option at risk-free interest rate of $3.87 \%$, which is bank interest rate for one-year.

$$
\begin{gathered}
165.42 P+33.08(1-P)=49.62 e^{0.0387} \\
P=0.1398
\end{gathered}
$$

That is to say, the probability of the call option is $13.98 \%$ of which value is 55.8 million $(165.42-50=$ 115.42 ). And the probability equals $1-P$ when the value of the call option is zero, that is $86.02 \%$.

Expected cash flow of the option to switch is:

$$
115.42 \times 13.98 \%+0 \times 86.02 \%=16.13
$$

Discount at the risk rate of $20 \%$, get current value of option to switch:

$$
16.13 /(1+20 \%)=13.44
$$

Therefore, project team will be able to share a part of this value as an incentive with real option incentive approach when finished the first phase. The firm can determine the proportion $\alpha_{i}$ as $10 \%$ based on strategic objective and current industry competition. So, R \& D team may get 1.344 million as a reward. It is reasonable for the both because this project can build foundation for another product's R \& D and contribute to the company's development. Considering that being start-up period and need more liquidity for more follow-up R \& D projects, the company decided not to use bonus but share the value of latter project in the future.

\subsection{Comparative Analysis about Advantage of Real Option}

The high-risk project is common for any firm. Real op- tion incentive put forwarded in this paper is one of ways to solve how to encourage R \& D team in such project, which advantages include: 1) to avoid short-term goaloriented, companies can determine benchmarks of team incentive based on the follow-up value of high-risk project; 2) To design more flexible incentive methods, companies can use different types of real option or design different exercise methods; 3 ) If we combine real option incentive with other motivation methods, the effect will be more targeted-oriented and more comprehensive.

\section{Conclusions}

This article discusses the method of real options to encourage $\mathrm{R} \& \mathrm{D}$ team when the enterprises can not achieve the desired economic benefit in the case of high-risk project or the immature market. The steps of method include: identify the real option type of high-risk projects, design the incentive mechanism and design specific exercise ways. In fact, real option presented in this paper can be applied not only to high-risk project, but also to other technical project. In addition, some non-material incentives, such as honor or job promotion, will bring more opportunities for R \& D team, which itself can be regarded as one of real options. How to quantify the value of these non-material incentives approach and combine with other materials will be our next research direction and focus.

\section{REFERENCES}

[1] F. Hu, "Incentive Compensation Study on R \& D Team," South China Normal University, Guangzhou, 2004.

[2] T. J. Englander, "Casey at the Bank," Incentive, Vol. 167, No. 2, 1993, p. 20.

[3] R. J. Doyle, "Caution: Self-Directed Work Teams," Human Resource Magazine, Vol. 37, No. 6, 1992, pp. 153-155.

[4] B. Geber, "The Bugaboo of Team Pay," Training, Vol. 32, No. 8, 1995, pp. 25-34.

[5] J. R. Hoffman and S. G. Rogelberg, "A Guide to Team Incentive Systems," Team Performance Management, Vol. 4, No. 1, 1998, pp. 23-32.

[6] S. Y. Chen, X. W. Tang, D. B. Ni et al., "Value Analysis on Non Material Incentive in Combination Incentive to Managers," Chinese Journal of Management Science, Vol. 13, No. 1, 2005, pp.122-126.

[7] W. J. Zhang and J. F. Li, "Motivation System in Chinese Knowledge-Enterprises," Science Research Management, Vol. 22, No. 6, 2001, pp. 90-96.

[8] X. Li and G. S. Zhang, "The Effect of Stock Option Incentive for Manager from the Team Theory," Business Times, Beijing, 2007.

[9] L. Yin, Z. Y. Zhao et al., "The Theory and Practice of Stock and Option Incentive for High-tech Enterprise," 
Science Press, Beijing, 2004.

[10] X. W. Yuna, Z. Qin and J. B. Yi, "Interplay Mechanism of Learning and Performance in Organizations," Science Research Management, Vol. 27, No. 6, 2006, pp. 80-85.

[11] S. F. Bi, D. S. Li and X. Ma, "The Application of Compound Option Method to the Project Evaluation," Science Research Management, Vol. 29, No. 3, 2008, pp. 109-113.

[12] C. Wu and H. H. Hu, "Research on the Long Term Incentive Mechanism under Executive's Management of Combined Investment," Chinese Journal of Management Science, Vol. 15, No. 6, 2007, pp. 125-131.

[13] Z. G. Zhang, "Study on R \& D Staff Incentive Payment Based on Compound option Model," Science of Science and Management of S.\& T., Vol. 28, No. 8, 2007, pp. 179-183.

[14] H. L. Ding, "The Path Research of Benefit Apportionment for Technology Elements," Journal of Nanjing Party Institute of $\mathrm{CPC}$ and Nanjing Administration Institute, Vol. 5, 2004, pp. 26-29.

[15] F. L. Chen and Z. G. Hu, "Research on Quantitative Apportionment Involving Technological Factors for Technology-oriented Enterprises," Science Research Management, Vol. 29, No. 2, 2008, pp. 89-96.

[16] C. P. Yang, "Real Option and its Application," Fudan University Press, Shanghai, 2003. 